\title{
Effect of Cu Content on the Semi-Solid Formability and Mechanical Properties of Ti-Cu Alloys
}

\author{
Chen Yongnan ${ }^{1}$, Huo Yazhou ${ }^{1}, \quad$ Zhao Yiping ${ }^{1}$, Song Xuding ${ }^{1}, \quad$ Zhao Yongqing ${ }^{2}$, \\ Bi Zhaozhao', Li Liao ${ }^{1}$
}

${ }^{1}$ Chang'an University, Xi'an 710064, China; ${ }^{2}$ Northwest Institute for Nonferrous Metal Research, Xi'an 710016, China

\begin{abstract}
The formability of $\mathrm{Ti}-\mathrm{Cu}$ alloys and their mechanical properties after semi-solid forging were investigated. The formability was evaluated by upsetting and die forging tests. Tensile test was also performed to study the mechanical properties of $\mathrm{Ti}-\mathrm{Cu}$ alloys after semi-solid forging. The results show that the semi-solid forging requires lower upsetting forces in the temperature range from $1000{ }^{\circ} \mathrm{C}$ to $1150{ }^{\circ} \mathrm{C}$ compared with conventional solid forging. Die forging tests show that the semi-solid forged Ti-Cu alloys have an excellent workability with a forging ratio of $75 \%$ in the temperature range from $1000{ }^{\circ} \mathrm{C}$ to $1050{ }^{\circ} \mathrm{C}$. $\mathrm{The}^{\mathrm{Ti}} \mathrm{Cu}_{2} \mathrm{Cu}$ phe increases with the increase of $\mathrm{Cu}$ content, and more liquid precipitates during semi-solid deformation at higher temperatures and higher $\mathrm{Cu}$ content, which relaxes the stress concentration caused by solid deformation and improves the formability. Tensile test reveals that semi-solid forged Ti-Cu alloys exhibit higher strength and lower ductility than conventional forged alloys. The Ti-Cu alloys have lower ductility and higher strength with the increasing of $\mathrm{Cu}$ content. The difference in tensile properties is attributed to the change of $\mathrm{Ti}_{2} \mathrm{Cu}$ precipitates at different $\mathrm{Cu}$ contents and semi-solid forging temperatures.
\end{abstract}

Key words: Ti-Cu alloy; semi-solid; formability; microstructure; mechanical properties

Semi-solid processing (SSP), developed at Massachusetts Institute of Technology (MIT) during the 1970s ${ }^{[1]}$, is a near-net-shape forming technology for metals, alloys and composites. The alloy with a suitable spheroidal microstructure is formed into near net-shape components at temperatures between the solidus and the liquidus. The components produced by SSP have higher mechanical properties and lower-casting defects such as porosity in comparison with those by conventional casting ${ }^{[2,3]}$. The near-net-shape production of complex parts can be achieved with lower pressure by SSP compared with conventional forging. Therefore, SSP has received considerable attentions in recent years.

The semi-solid deformation and processing behaviors of $\mathrm{Al}$ alloys ${ }^{[4-6]}, \mathrm{Mg}$ alloys ${ }^{[7-9]}$ and steel ${ }^{[10]}$ were investigated all over the world, and many achievements have been obtained. However, the previous researches on the deformation behavior and processing technology of titanium alloys were conducted by the solid state forming, and the main results showed that titanium and its alloys are difficult to be fabricated in solid state due to their poor formability such as high strength, relatively low elastic modulus, high chemical reactivity, and high energy cost ${ }^{[11]}$. In order to improve the formability of titanium alloys, our group investigated the semi-solid deformation behaviors of $\mathrm{Ti}-14 \mathrm{Cu}$ alloy, and it was shown that a lower deformation resistance could be obtained in semi-solid temperature range from $1000{ }^{\circ} \mathrm{C}$ to $1100{ }^{\circ} \mathrm{C}^{[12-15]}$. The $\mathrm{Cu}$ composition and processing have significant effects on the microstructure and the mechanical properties of $\mathrm{Ti}-\mathrm{Cu}$ alloy, as reported by Kikuchi ${ }^{[16,17]}$, Bhaskan ${ }^{[18]}$, and Souza et al ${ }^{[19]}$. However, no further work

Received date: August 02, 2015

Foundation item: The Project of "973" Program (2007CB613807); National Natural Science Foundation of China (51201019, 51401033)

Corresponding author: Chen Yongnan, Ph. D., Associate Professor, School of Materials Science and Engineering, Chang'an University, Xi'an 710064, P. R. China, Tel: 0086-29-82334590,E-mail: frank_cyn@163.com 
was performed on the specific effect of $\mathrm{Cu}$ content on the formability and the microstructure of $\mathrm{Ti}-\mathrm{Cu}$ alloy during semi-solid processing. In the present work, upsetting and die forging tests were performed to understand the semi-solid formability, the microstructures and the properties of the hypo-, hyper- and eutectoid Ti-Cu alloys after semi-solid processing. In addition, a room temperature tensile test was performed to investigate the influence of $\mathrm{Cu}$ content and forging temperature on mechanical properties, which may provide bases for the breakthrough of titanium alloys processing technology.

\section{Experiment}

Ti-Cu alloys with different $\mathrm{Cu}$ contents (2.5, 7.0 and 14.0, wt $\%)$ were investigated. The alloys used in the present paper were a new $\alpha+\mathrm{Ti}_{2} \mathrm{Cu}$ type of $\mathrm{Ti}$ alloy. The chemical compositions of the experimental alloys are presented in Table 1 . The melting point of $\mathrm{Ti}_{2} \mathrm{Cu}$ is $990{ }^{\circ} \mathrm{C}$, which means the $\mathrm{Ti}_{2} \mathrm{Cu}$ will be transformed to liquid and the alloy will change to a semi-solid state when the deformation or testing temperature goes up to $990{ }^{\circ} \mathrm{C}$.

Formability was investigated by upsetting and die forging tests. In the upsetting test, a cylindrical specimen of $15 \mathrm{~mm}$ diameter and $22 \mathrm{~mm}$ height was compressed between concentrically-grooved platens on a mechanical press. The occurrence of surface cracking was checked at each reduction in height by the naked eye. The flow stress of the material was also calculated from the upsetting load.

A die made of WC with approaching angle of $120^{\circ}$ was used for the die forging tests, as shown in Fig.1. The specimens were primarily forged to bars with a diameter of $40 \mathrm{~mm}$, and then semi-solid forged at 1000,1050 and $1100{ }^{\circ} \mathrm{C}$ with a forming speed of $500 \mathrm{~mm} / \mathrm{min}$. The reduction of area (forging ratio $75 \%$ ) was performed by changing the die hole diameter from 40 to $20 \mathrm{~mm}$. Specimens were heated by an induction heater before the test and the dies were coated with an oil lubricant. The surface temperature of the specimen was measured by a radiation thermometer prior to the test.

Phase identification was determined by X-ray diffraction techniques (XRD, XRD-1700). Microstructures after the forging were analyzed by optical microscopy (OM, OLYMPUS GX71), scanning electron microscopy (SEM, JSM-6700), and transmission electron microscopy (TEM, JEM-200CX). SEM and TEM studies were carried out to investigate precipitate morphology and dislocation density. TEM foils were prepared by twin jet electropolishing in a solution of $95 \%$ (vol\%) methanol and $5 \%$ perchloric acid at $15 \mathrm{~V}$ and $\sim 30{ }^{\circ} \mathrm{C}$.

The mechanical properties of the $\mathrm{Ti}-\mathrm{Cu}$ alloys after semi-solid forging were evaluated by tensile tests at room temperature. Tensile specimens with a diameter of $4 \mathrm{~mm}$ and a gage length of $45 \mathrm{~mm}$ were taken from the center of
Table 1 Chemical compositions of Ti-Cu alloy(wt\%)

\begin{tabular}{ccccc}
\hline $\mathrm{Ti}-\mathrm{Cu}$ & $\mathrm{Cu}$ & $\mathrm{Al}$ & $\mathrm{Si}$ & $\mathrm{Ti}$ \\
\hline $\mathrm{Ti}-2.5 \mathrm{Cu}$ & 2.5 & 0.3 & 0.7 & $\mathrm{Bal}$ \\
$\mathrm{Ti}-7 \mathrm{Cu}$ & 7.0 & 0.3 & 0.7 & $\mathrm{Bal}$ \\
$\mathrm{Ti}-14 \mathrm{Cu}$ & 14.0 & 0.3 & 0.7 & $\mathrm{Bal}$ \\
\hline
\end{tabular}

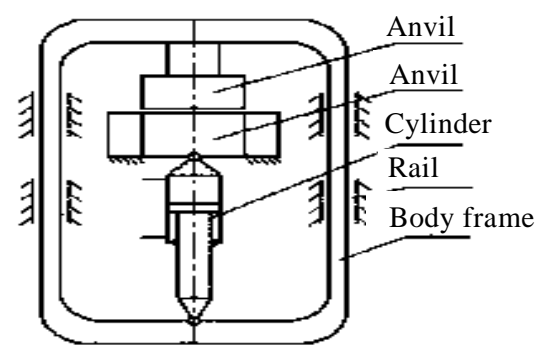

Fig.1 Diagrammatic sketch of die forging structure

forged bar. Tensile tests were performed at a nominal strain rate of $4.2 \times 10^{-3} \mathrm{~s}^{-1}$ using an Instron System at room temperature. After the tensile test, the fractured surface morphology was examined by scanning electron microscopy (SEM, JSM-6700) and optical microscopy (OM, OLYMPUS GX71).

\section{Results}

\subsection{Upsettability}

In the process of semi-solid processing, the critical reduction in height $\left(\delta_{\text {cr }}\right)$ at which cracks occur on the lateral surfaces of all the upset specimens is 70\% 85\% in the temperature range from $1000{ }^{\circ} \mathrm{C}$ to $1150{ }^{\circ} \mathrm{C}$, whereas in the case of the warm-forging processing, it is quite lower $(60 \%)$ than in semi-solid processing, as shown in Fig.2a. The peak value of $\delta_{\mathrm{cr}}$ increases with the increasing of $\mathrm{Cu}$ content, and a maximum $\delta_{\text {cr }}$ of $85 \%$ is observed in Ti- $14 \mathrm{Cu}$ alloy after upsetting at $1050{ }^{\circ} \mathrm{C}$. Moreover, a minimum level is observed after the peak value, where liquid seems to seep from the inside to the lateral surface.

Fig.2b shows the temperature dependence of the maximum flow stress at a strain rate of $0.5 \mathrm{~s}^{-1}$. It is obvious that all semi-solid upset specimens exhibit lower maximum flow stresses compared with warm-forged one. The maximum flow stress after upsetting increases with the increasing of $\mathrm{Cu}$ content in solid state and decreases with the increasing of $\mathrm{Cu}$ content in semi-solid state. This suggests that the upsetting force required in semi-solid processing is much lower than that required in conventional processing, especially with high $\mathrm{Cu}$ content, and the semi-solid forming leads to excellent upsettability of $\mathrm{Ti}-\mathrm{Cu}$ alloys in the temperature range from $1000{ }^{\circ} \mathrm{C}$ to $1150{ }^{\circ} \mathrm{C}$.

\subsection{Characteristics of die forging test}

Fig. 3 displays the results of die forging tests in solid and semi-solid state with a forging ratio of $75 \%$ at the forging speed of $500 \mathrm{~mm} / \mathrm{min}$ and different temperatures. Obvious surface cracks can be observed in all conventionally forged 

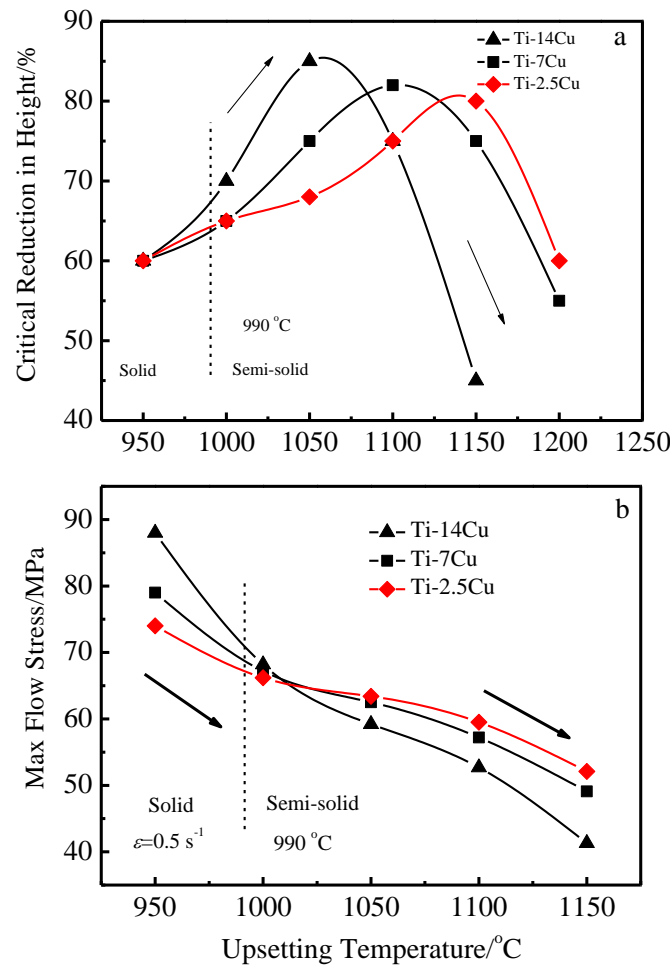

Fig.2 Upsetting temperature dependence of critical reduction in height (a) and max flow stress (b)
Ti-Cu alloys. In addition, the partial surface has desquamated and cracked in Ti-14Cu alloy after semi-solid forging at $1100{ }^{\circ} \mathrm{C}$. The reason for this phenomenon is that more liquid flows and leaks on the surface under the compressive stress. The forging process can be completed without significant surface cracks at 1000 and $1050{ }^{\circ} \mathrm{C}$ for all $\mathrm{Ti}-\mathrm{Cu}$ alloys. The result indicates that the formability is improved during the semi-solid process. It is also noticed that the temperature and $\mathrm{Cu}$ content affect the formability of titanium alloy, and in particular, the formability is strongly dependent on the temperature.

\subsection{Microstructural characteristics of $\mathrm{Ti}-\mathrm{Cu}$ alloy after semi-solid forging}

The results of XRD test and microstructural features corresponding to various $\mathrm{Cu}$ contents and forging temperatures are shown in Fig.4 and Fig.5, respectively. No $\beta$ phase is found in the samples after semi-solid forging irrespective of the temperature, and the microstructures of all samples mainly consist of $\alpha$-Ti matrix and $\mathrm{Ti}_{2} \mathrm{Cu}$ precipitate phase. $\mathrm{Ti}_{2} \mathrm{Cu}$ precipitation is formed both in internal grains and at grain boundaries in all the samples.

The $\mathrm{Ti}-2.5 \mathrm{Cu}$ alloy and the $\mathrm{Ti}-14 \mathrm{Cu}$ alloy show a typical hypo-eutectoid and hyper-eutectoid structure (Figs.5a 5c and Figs.5g 5i), including the primary precipitates $\alpha$-Ti, the eutectoid $\alpha$-Ti and $\mathrm{Ti}_{2} \mathrm{Cu}$ transforming from $\beta$-Ti at eutectoid temperature. Figs.5d 5f essentially show a

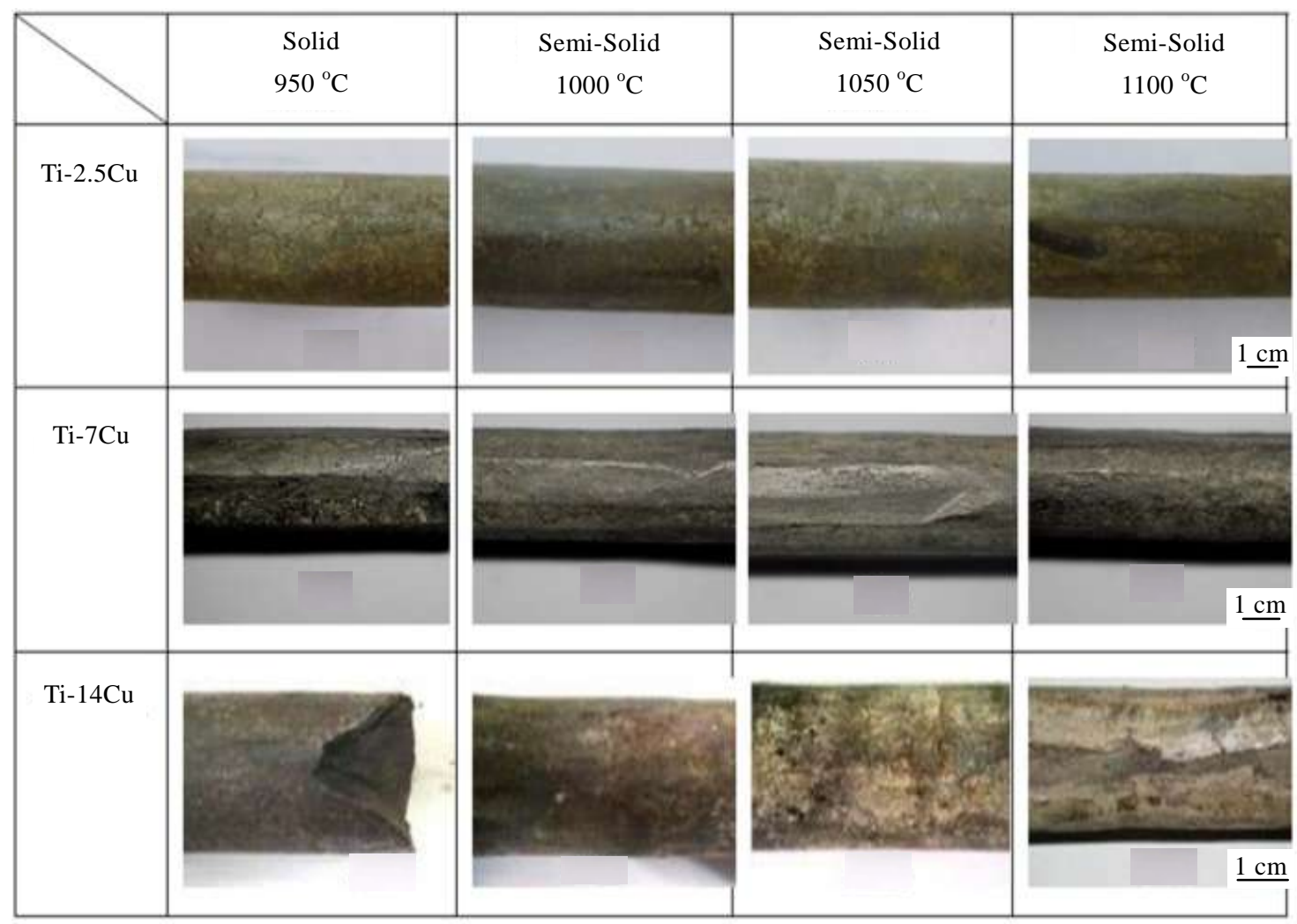

Fig.3 Results of die forging tests at $950,1000,1050$, and $1100{ }^{\circ} \mathrm{C}$ with forging ratio $75 \%$, at forging speed of $500 \mathrm{~mm} / \mathrm{min}$ 
eutectoid structure, since the $\mathrm{Cu}$ content of samples is just at the eutectoid point $(7.0 \% \mathrm{Cu})$. The $\mathrm{Cu}$ content has significant effects on the distribution and shape of $\mathrm{Ti}_{2} \mathrm{Cu}$ precipitates, especially at higher semi-solid forging temperatures. SEM images of the Ti-Cu alloys after forging at $1100{ }^{\circ} \mathrm{C}$ are shown in Fig. 6. The grain boundaries of the $\mathrm{Ti}-2.5 \mathrm{Cu}$ alloy forged at $1100{ }^{\circ} \mathrm{C}$ mainly consist of $\mathrm{Ti}_{2} \mathrm{Cu}$ particle precipitates (Fig.6a). As the $\mathrm{Cu}$ content increases, more acicular intermetallic phase is observed at the grain boundaries, which is identified as eutectoid $\mathrm{Ti}_{2} \mathrm{Cu}$ $(39.9 \mathrm{wt} \% \mathrm{Cu})^{[16-18]}$. Ordinary EDS measurements are consistent with the observation and give $\mathrm{Cu}$ content of $36.94 \mathrm{wt} \%$ for the acicular precipitates. As a result, macrosegregation of $\mathrm{Ti}_{2} \mathrm{Cu}$ occurs and more acicular $\mathrm{Ti}_{2} \mathrm{Cu}$ precipitate on grain boundaries at higher $\mathrm{Cu}$ content, which leads to the formation of gross precipitated zones adjacent to grain boundaries and finally a net-structure is formed as shown in Ti-14Cu alloy after forged at $1100{ }^{\circ} \mathrm{C}$ (Fig.5i and Fig.6c).

\subsection{Mechanical properties}

The values of ultimate tensile strength, yield strength and elongation for each sample are summarized in Fig.7.
Compared with conventional forged $\left(950{ }^{\circ} \mathrm{C}\right) \mathrm{Ti}-\mathrm{Cu}$ alloys, all the alloys after semi-solid forging exhibit higher strength and lower ductility. The ultimate tensile strength and yield strength increase with the increasing of $\mathrm{Cu}$ content, and a maximum strength is obtained in $\mathrm{Ti}-14 \mathrm{Cu}$ alloy after forging at $1000{ }^{\circ} \mathrm{C}$. The elongation of the Ti-14Cu alloy has a significantly lower value than other alloys tested, and only 3\% elongation is obtained after forging at $1100{ }^{\circ} \mathrm{C}$. The tensile tests results reveal that the

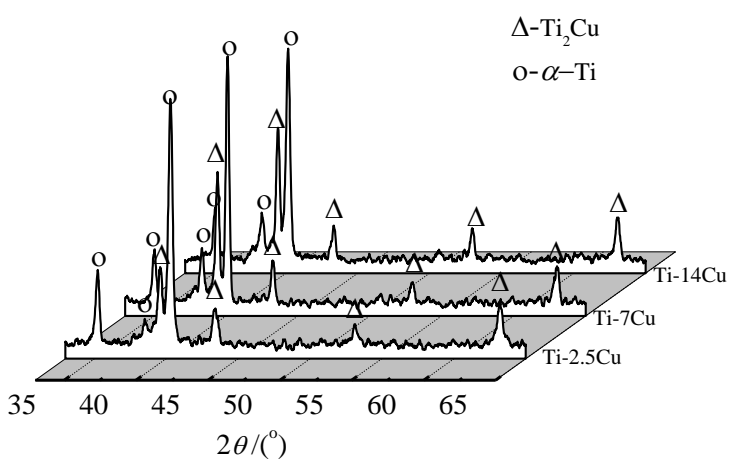

Fig.4 XRD patterns of Ti-Cu alloys after forging at $1050{ }^{\circ} \mathrm{C}$
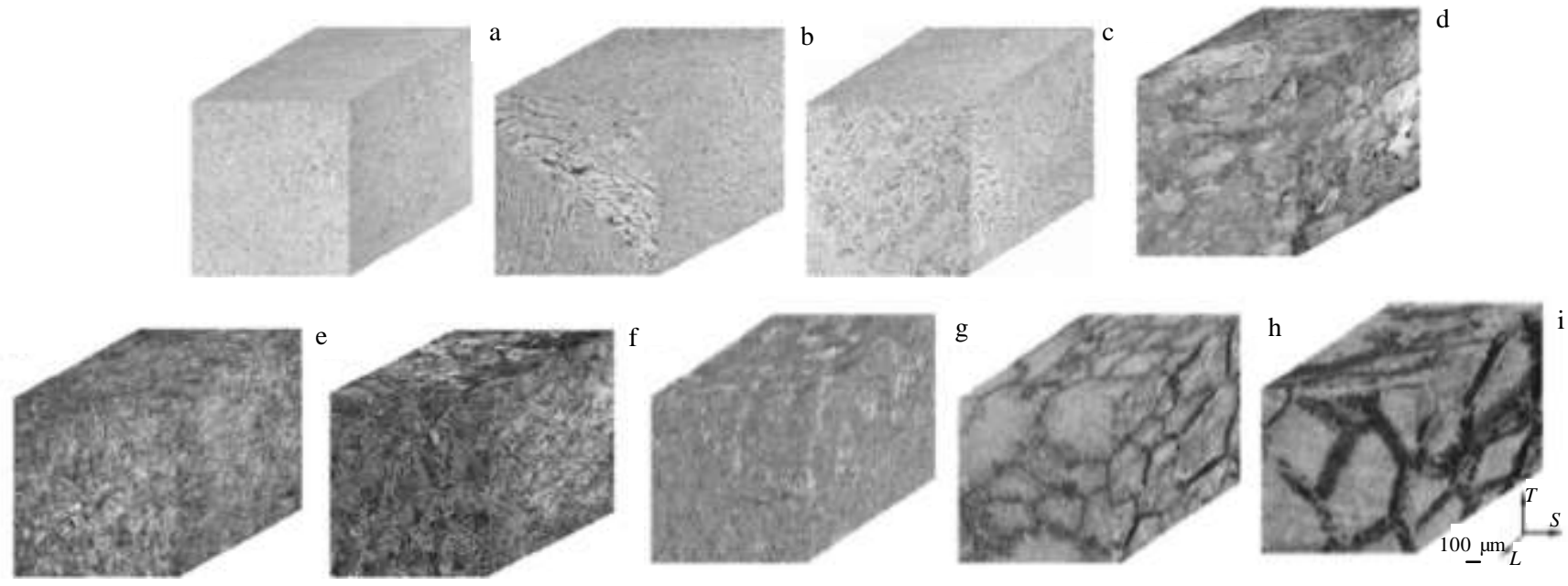

Fig.5 Three-dimensional microstructures of titanium alloys under different conditions: $\mathrm{Ti}-2.5 \mathrm{Cu}$ (a) $1000{ }^{\circ} \mathrm{C}$, (b) $1050{ }^{\circ} \mathrm{C}$, (c) $1100{ }^{\circ} \mathrm{C}$; $\mathrm{Ti}-7 \mathrm{Cu}(\mathrm{d}) 1000{ }^{\circ} \mathrm{C}$, (e) $1050{ }^{\circ} \mathrm{C}$, (f) $1100{ }^{\circ} \mathrm{C}$; $\mathrm{Ti}-14 \mathrm{Cu}(\mathrm{g}) 1000{ }^{\circ} \mathrm{C}$, (h) $1050{ }^{\circ} \mathrm{C}$, (i) $1100{ }^{\circ} \mathrm{C}$

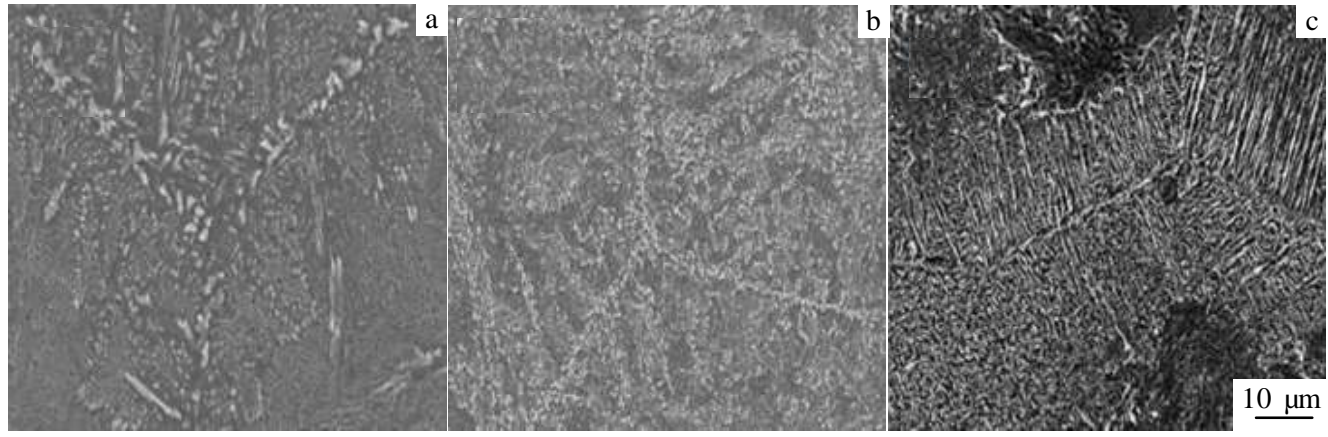

Fig.6 SEM images of Ti-Cu alloy after $1100{ }^{\circ} \mathrm{C}$ forging: (a) Ti-2.5Cu, (b) Ti-7Cu, and (c) Ti-14Cu alloy 
increase of $\mathrm{Cu}$ content could improve the strength and reduce the ductility of $\mathrm{Ti}-\mathrm{Cu}$ alloys, especially after semi-solid forging.

\subsection{Fracture analysis}

Fig. 8 illustrates the SEM fractographs of Ti-Cu alloys after semi-solid forging at $1100{ }^{\circ} \mathrm{C}$. The fracture morphology of $\mathrm{Ti}-2.5 \mathrm{Cu}$ alloy is fully consists of tiny dimple, which is a typical transgranular fracture, indicating good plasticity of the sample (Fig.8a). Typical intergranular fracture is clearly observed in Fig.8b and 8c. In those specimens, delamination of precipitates and matrix is the principal mechanism for the nucleation of microcracks within the grains. When these microcracks propagate and reach the coarse grain boundaries, the cracks are deflected and follow the grain boundaries, and lead to the intergranular fracture. It seems reasonable to assume that the low ductility is related to these precipitates.

\section{Discussion}

\subsection{Semi-solid formability of the $\mathrm{Ti}-\mathrm{Cu}$ alloys}

Previous research on the semi-solid formability of $\mathrm{Mg}-\mathrm{Al}$ alloy claimed that the liquid could serve to relax the stress concentrations caused by the dominant deformation process and accelerate the flow of the solid ${ }^{[4-7]}$. Similar upsetting and die forging results are obtained in the present study. Fig.9 shows the dislocation patterns in $\mathrm{Ti}-\mathrm{Cu}$ alloys after semi-solid forging at $1100{ }^{\circ} \mathrm{C}$. It seems that more liquid is precipitated at high $\mathrm{Cu}$ content and/or at higher semi-solid
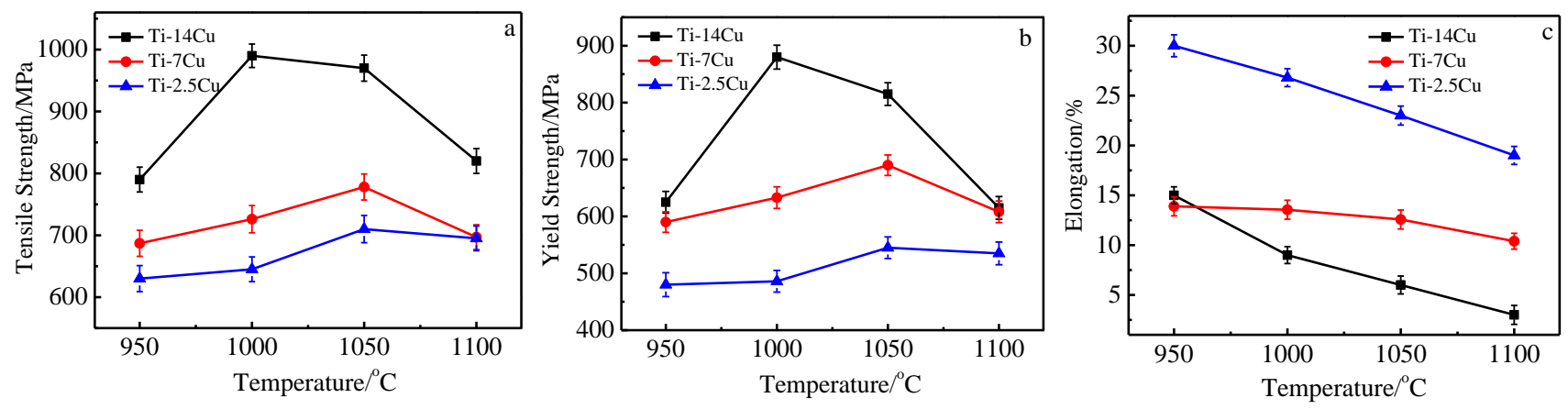

Fig.7 Room temperature tensile properties of Ti-Cu alloys: (a) ultimate tensile strength, (b) yield strength, and (c) elongation

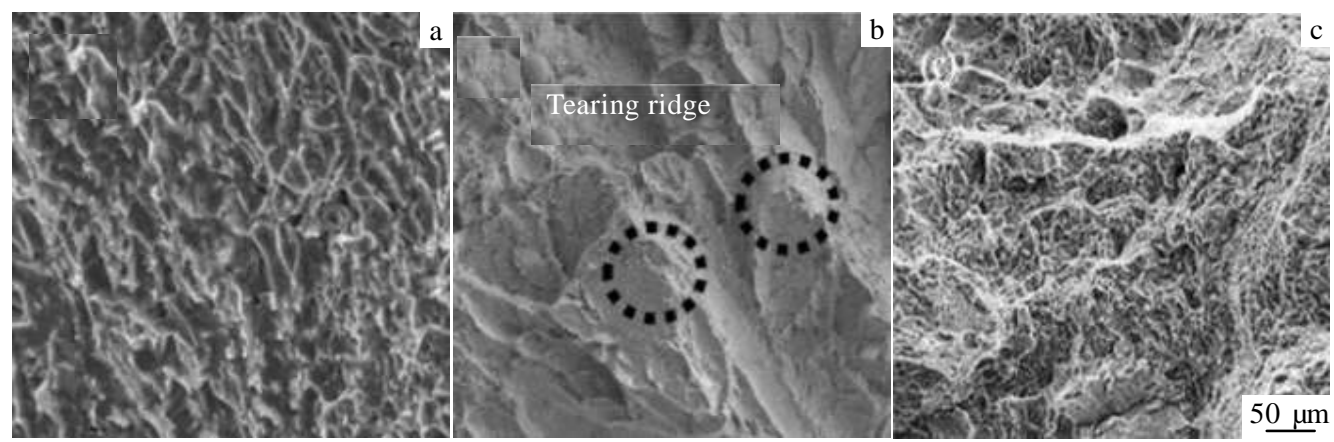

Fig.8 Tensile fracture morphologies of Ti-Cu alloys after forging at $1100{ }^{\circ} \mathrm{C}$ : (a) $\mathrm{Ti}-2.5 \mathrm{Cu}$, (b) $\mathrm{Ti}-7 \mathrm{Cu}$, and (c) $\mathrm{Ti}-14 \mathrm{Cu}$ alloy
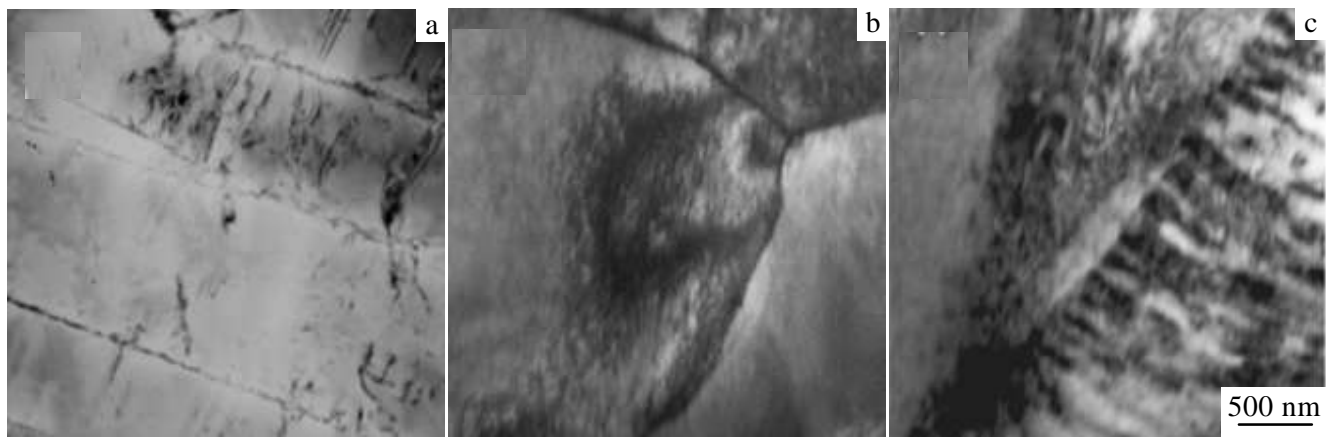

Fig.9 Grain boundary dislocation configuration of Ti-Cu alloys: (a) Ti-2.5Cu, (b) Ti-7Cu, and (c) Ti-14Cu alloy 
temperature, which relaxes the stress concentrations caused by dislocation pile-ups within the grains, and leads to a low dislocation density within the grains and a high dislocation density at grain boundaries. In addition, more liquid could flow and leak on the surface by grain boundaries under higher compressive stress $(75 \%$ forging ratio) and/or higher temperature $\left(1100{ }^{\circ} \mathrm{C}\right)$, which is harmful for forging because of the macrosegregation of $\mathrm{Ti}_{2} \mathrm{Cu}$ at grain boundaries (as shown in Fig.5i and 5f). Thus, in our test, excellent formability of $\mathrm{Ti}-\mathrm{Cu}$ alloy could be obtained at semi-solid forging temperatures between $1000 \sim 1050{ }^{\circ} \mathrm{C}$.

\subsection{Effect of $\mathrm{Cu}$ content on the mechanical properties of the $\mathrm{Ti}-\mathrm{Cu}$ alloys after semi-solid forging}

The tensile strength of the $\mathrm{Ti}-\mathrm{Cu}$ alloys increases with the increasing of $\mathrm{Cu}$ content, especially after semi-solid forging, probably due to the solid solution strengthening and precipitation hardened effect caused by different $\mathrm{Cu}$ contents and semi-solid processing parameters. On the other hand, the elongation tends to decrease rapidly with the increasing of the $\mathrm{Cu}$ content and forging temperature, resulting in the lowest elongation for the $\mathrm{Ti}-14 \mathrm{Cu}$ alloy after forging at $1100{ }^{\circ} \mathrm{C}$. The precipitation hardened effect of $\mathrm{Ti}_{2} \mathrm{Cu}$ precipitates might be the main reason for the increase in tensile strength ${ }^{[20-23]}$. A decrease in ductility is also observed in OM fractography as shown in Fig. 10. Cleaved grains which are characteristic of the decrease in ductility are observed in the Ti-14Cu alloy (Fig.10c and 10d), attributed to the precipitate zone along the grain boundaries. This is the principal mechanism for the nucleation of microcracks and the intergranular fracture.

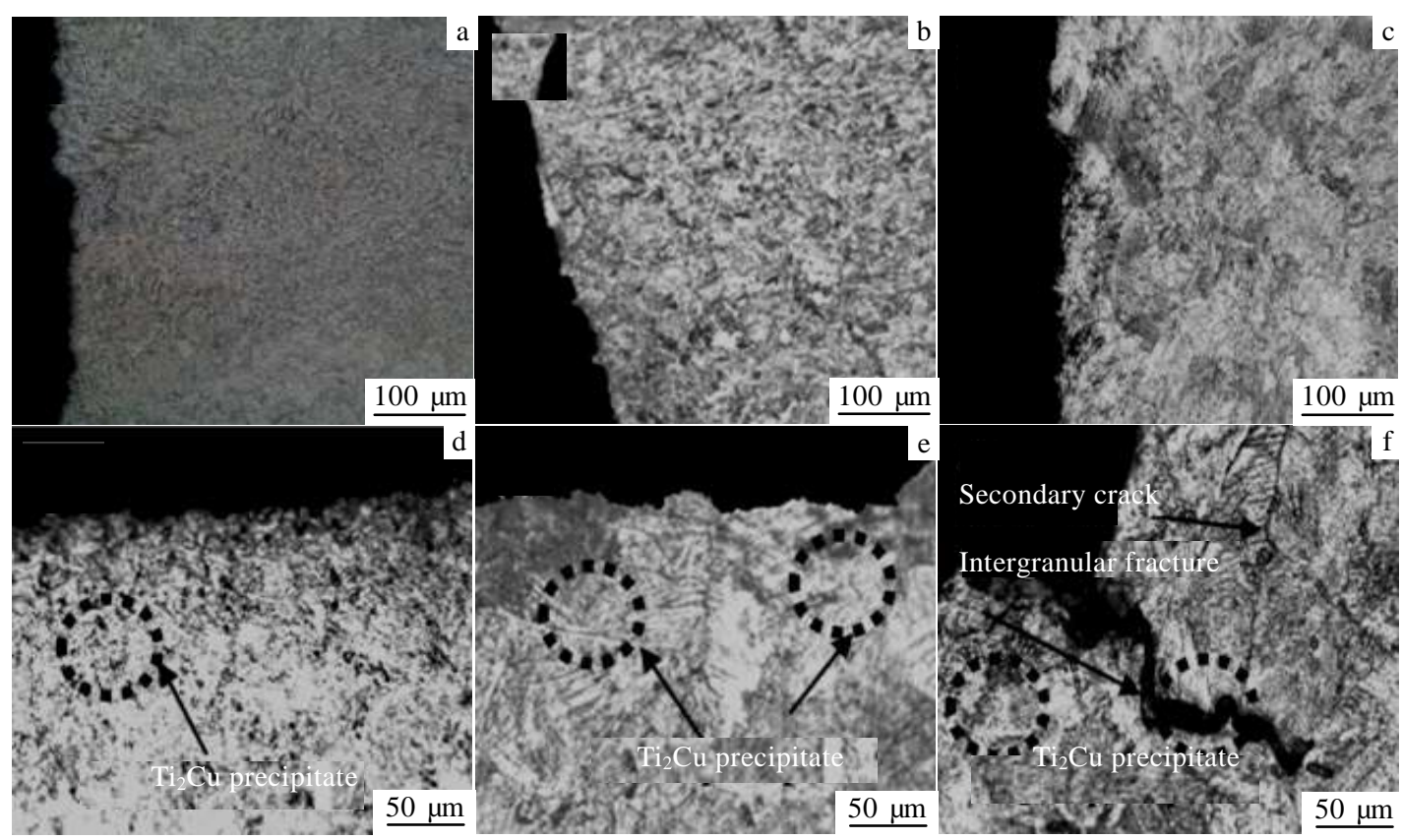

Fig.10 Fracture profiles of Ti-Cu alloys after forging at $1100{ }^{\circ} \mathrm{C}:(\mathrm{a}, \mathrm{d}) \mathrm{Ti}-2.5 \mathrm{Cu},(\mathrm{b}, \mathrm{e}) \mathrm{Ti}-7 \mathrm{Cu}$, and (c, f) Ti-14Cu alloy

\section{Conclusions}

1) The formability of semi-solid state $\mathrm{Ti}-\mathrm{Cu}$ alloys is better than that of solid state ones. The alloys can be upset up to almost $70 \% \sim 85 \%$ reduction in height in semi-solid temperature range from $1000{ }^{\circ} \mathrm{C}$ to $1150{ }^{\circ} \mathrm{C}$ without cracking, and much lower upsetting force is required.

2) The $\mathrm{Cu}$ content of the $\mathrm{Ti}-\mathrm{Cu}$ alloys affects the fraction, the shape, and the distribution of $\mathrm{Ti}_{2} \mathrm{Cu}$ precipitates. Macrosegregation of $\mathrm{Ti}_{2} \mathrm{Cu}$ occurs at grain boundaries and more acicular $\mathrm{Ti}_{2} \mathrm{Cu}$ tends to precipitate at grain boundaries at higher $\mathrm{Cu}$ content and/or semi-solid forging temperature, and gross precipitate zones are formed along the grain boundaries in the $\mathrm{Ti}-14 \mathrm{Cu}$ alloy semi-solid forged at $1100{ }^{\circ} \mathrm{C}$. These precipitate zones are harmful for forging and mechanical properties of $\mathrm{Ti}-\mathrm{Cu}$ alloys.

3) The tensile strength of the Ti-Cu alloys increases and elongation decreases with the increase of the $\mathrm{Cu}$ content, especially after semi-solid forging. The difference in tensile strength is associated with the distribution of the $\mathrm{Ti}_{2} \mathrm{Cu}$ precipitates resulting from the different $\mathrm{Cu}$ contents and/or forging temperatures. The formation of extensive grain boundary precipitated zones leads to a significant reduction in ductility and causes intergranular fracture at $\mathrm{Ti}-14 \mathrm{Cu}$ alloy. 


\section{References}

1 Flemings M C. Solidification Processing[M]. New York: McGraw Hill, 1974: 160

2 Lutjering G, Williams J C. Titanium[M]. New York: Springer, 2003: 178

3 Donachie M J. Titanium a Technical Guide[M]. New York: Springer, 2003: 115

4 Eskin D G, Suyitno, Katgerman L. Pro Mater Sci[J], 2004, 49:629

5 Iwaski H, Mori T. Acta Mater[J], 1998, 46: 6351

6 Möller H, Curle U A. Trans Nonferrous Met Soc China[J], 2010, 20: 847

7 ChinoY, Iwasaki H. Acta Mater[J], 2003, 51: 3309

8 Hu K, Phillion A B. Scripta Mater [J], 2009, 60: 427

9 Khosravani A, Aashuri H. J Alloy Compd [J], 2009, 477: 822

10 PutgenW, Hallstedt B, Bleck W. Acta Mater[J], 2007, 55: 6553
11 Zhou L, Luo G Z. Mater Sci Eng A[J], 1988, 243: 294

12 Zhao Y Q, Wu W L. Mater Sci Eng A [J], 2004, 373: 315

13 Chen Y N, Wei J F, Zhao Y Q. Mater Sci Eng A[J], 2009, 520: 16

14 Chen Y N, Wei J F, Zhao Y Q. Rare Met Mater Eng[J], 2012, 41(1): 0199 (in Chinese)

15 Chen Y N, Wei J F, Zhao Y Q. Rare Met Mater Eng[J], 2012, 41(2): 0581 (in Chinese)

16 Kikuchi M, Takada Y. Dental Materials[J], 2003, 19: 375

17 Kikuchi M, Takada Y. Dental Materials[J], 2003, 19: 174

18 Bhaskan T A, Krishanan, Scripta Meta[J], 2004, 19: 319

19 Souza A, Afonc C R. Mater Sci Eng C[J], 2009, 29: 1023

20 Yao X, Sun Q Y. J Alloy Compd[J], 2009, 484: 196

21 Nagarjuna S, Sarmad S. Scripta Meta[J], 1999, 41: 359

22 Nagarjuna S, Chinta U. Mater Sci Eng A[J], 2008, 491: 33

23 Nagarjuna S, Srinivas M. Mater Sci Eng A[J], 2005, 406: 186

\title{
$\mathrm{Cu}$ 含量对 Ti-Cu合金半固态可锻性及锻造后力学性能的影响
}

\author{
陈永楠 $^{1}$, 霍亚洲 ${ }^{1}$, 赵祎平 ${ }^{1}$, 宋绪丁 ${ }^{1}$, 赵永庆 ${ }^{2}$, 毕朝朝 ${ }^{1}$, 李 撩 $^{1}$ \\ (1. 长安大学, 陕西 西安 710064) \\ (2. 西北有色金属研究院，陕西 西安 710016)
}

\begin{abstract}
摘 要: 通过镦锻试验和模锻实验研究了 $\mathrm{Ti}-\mathrm{Cu}$ 系合金半固态锻造行为, 并对锻材进行了拉伸试验, 讨论了 $\mathrm{Cu}$ 含量对半固态可锻性 及力学性能的影响。结果表明: $1000{ }^{\circ} \mathrm{C}$ 至 $1150{ }^{\circ} \mathrm{C}$ 半固态锻造较常规锻造具有较小的顶锻压力; 其中, $1000{ }^{\circ} \mathrm{C}$ 至 $1050{ }^{\circ} \mathrm{C}$ 间半固态 锻造的 $\mathrm{Ti}-\mathrm{Cu}$ 系合金均表现出较好的可锻性, 在 $75 \%$ 的锻造变形量下无明显缺陷。分析认为, $\mathrm{Ti}-\mathrm{Cu}$ 系列合金中含有较多的低熔点 $\mathrm{Ti}_{2} \mathrm{Cu}$ 相, 随着半固态温度升高或 $\mathrm{Cu}$ 含量的增加, 材料中的液相含量增加, 增加的液相含量对变形起到润滑作用, 减少了固相变形引起的 应力集中, 有效地降低了变形抗力, 改善了成形性。力学性能研究表明: 半固态锻造 Ti-Cu 系合金较常规锻造合金强度升高, 塑性降 低。随着 $\mathrm{Cu}$ 含量的升高, 合金的强度明显提升, 塑性降低。分析认为: 力学性能的变化主要是由于 $\mathrm{Ti}_{2} \mathrm{Cu}$ 相析出含量、形态和分布 相关, 随着 $\mathrm{Cu}$ 含量和半固态温度的升高, 更多 $\mathrm{Ti}_{2} \mathrm{Cu}$ 相在晶内和晶界析出, 引起析出强化作用, 同时, 晶界析出的针状 $\mathrm{Ti}_{2} \mathrm{Cu}$ 相形成 了偏析带, 降低了合金塑形。
\end{abstract}

关键词: $\mathrm{Ti}-\mathrm{Cu}$ 合金; 半固态; 成形性; 组织; 力学性能

作者简介: 陈永楠, 男, 1981 年生, 博士, 副教授, 长安大学材料科学与工程学院, 陕西 西安 710064, 电话: 029-82334590, E-mail: frank_cyn@163.com 